\title{
Dividend policy and share price volatility: empirical evidence from Vietnam
}

\author{
Thanh Hieu Nguyen ${ }^{a *}$ Huu Anh Nguyena, Quang Chung Tran ${ }^{a}$ and Quynh Lien Le
}

\begin{tabular}{l}
${ }^{a}$ National Economics University, \\
\hline C H R O N I C L E \\
\hline Article history: \\
Received November 252019 \\
Received in revised format \\
November 262019 \\
Accepted December 202019 \\
Available online \\
December 252019 \\
\hline Keywords: \\
Dividend \\
Firm \\
Growth rate \\
Investor \\
Manager \\
Volatility
\end{tabular}

\section{A B S T R A C T}

This paper was conducted to examine the relationship between dividend policy and share price volatility of companies listed on Hochiminh Stock Exchange (HOSE) in Vietnam. Data set used in this research was compiled from financial statements of 260 listed firms on HOSE from 2009 to 2018. Three statistical approaches employed to address econometrics issues as well as to improve the accuracy of the regression coefficients like fixed effects model (FEM), random effects model (REM) and general method of movement (GMM). Based on the results from GMM, the association between share price volatility and dividend yield, dividend payout ratio has been explored. The findings show a positive relationship between dividend yield and stock price volatilities and a negative relationship between dividend payout ratio and stock price volatility. In addition, it is found that a firm's growth rate, leverage and earnings volatility had positive influences on share price volatility while firm's size had negative effect on share price volatility.

\section{Introduction}

Stock price volatility is a change in the price of a stock relative to its average value. It also used to define the risk of a common stock, whereby, the greater the volatility of a common stock, the greater its risk. From an investor's viewpoint, understanding share price volatility is crucial. Stocks that move by larger margins can be more profitable on the upside, but they also carry greater risk of loss. In general, there are three schools of thought related to the relationship between dividend policy and stock price. The first school of thought suggests that dividend policy has no effect on stock price; hence the value of the firm in a perfect capital market will not be affected (Miller \& Modigliani, 1961; Black \& Scholes, 1974). The second school of thought claims that dividends are bad for the average stockholder because of tax disadvantage which will result in lower value (Brennan,1971). Finally, the bird-in-the-hand school of thought argue that dividends are favorable and will lead to an increase in the wealth of the shareholders through its influence on stock price (Harkavy, 1953; Gordon, 1963; Pettit, 1972; Ball et al., 1979; Woolridge, 1983). Over the years, share price volatility topic has been interested in both developed markets and developing markets. The studies not only focus on dividend policy affecting share price volatility, but also consider other factors such as: volatility of profit, firm size, debt to total assets ratio and growth rate. However, it is clear that: evidence in regard to the effect of dividend policy and other control variables on share price volatility is inconclusive. This paper is aimed at establishing a relationship between dividend policy and share price volatility, with particularly focus on the Vietnam stock market. We employ correlation and regressions in order to establish the extent to which dividend policies of firms in Vietnam affect their share price volatility.

* Corresponding author.

E-mail address: hieu39ktqd@gmail.com (T. Hieu Nguyen) 
The remainder of this article is structured in five sections, including Section 2: Theoretical Basis and Literature Review, Section 3: Research Hypotheses, Section 4: Research Methodology, Section 5: Empirical results on the dividend policy and share price volatilities of Vietnamese non-financial listed companies, Discussion and Recommendations and Conclusion are given in the last section.

\section{Theoretical basis and literature review}

\subsection{Theoretical basis}

If a stock is labelled as volatile, its price would greatly vary over time, and it is quite difficult to say with certainty what its future price will be. Investors prefer less risk. The lesser the amount of risk, the better the investment is (Kinder, 2002). In other words, the lesser the volatility of a given stock, the greater its desirability is. The volatility of ordinary stock is a measure used to define risk and represents the rate of change in the price of a stock over a given time: the greater the volatility, the greater the chance of a gain or loss in the short run. In early corporate finance, dividend policy referred to a corporation's choice of whether to pay its shareholders a cash dividend or to retain its earnings. It addressed the frequency of such payments (annually, semiannually or quarterly) and how much the company should pay. At its first beginnings, Miller and Modigliani (1961) illustrated the irrelevance of dividends and that it had no influence on share prices. Since then, those researchers and practitioners that have disagreed with this theory introduced competing theories and hypotheses to illustrate the fact that dividends do matter in an imperfect capital market. These theories and hypotheses include the bird-in-hand theory, signaling theory, agency cost, stakeholder's theory and clientele effect. Predating the irrelevance theory of Miller and Modigliani (1961), according to birdin-hand theory, investors prefer cash flow from dividends rather than cash flow from capital gains. Because the cash flow coming from dividends is the cash flow that investors are sure to receive immediately, while the capital gain from the success of the company's reinvestment in the future is unlikely sure. Therefore, bird in hand theory suggest that firms should set a high dividend payout ratio in order to maximize share price. This is because investors prefer dividends, which are certain, over retained earnings, which are less certain (Lintner, 1956; Walter, 1963)

The signaling theory proposed in the early 1980s, formed the base for another explanation of why dividend policy has been so popular. Signaling theory, or information content hypothesis, states that dividend payments carry information, which is a signal for investors. Because of the information asymmetry phenomenon, investors always hold less information about the company than the management, so they think dividends carry the information that managers want to convey (Bhattacharya, 1979). Advocates of signaling theories theory suggest that the separation of ownership along with the information asymmetry that exists between managers and outside shareholders, allows the managers to use dividends as a tool to signal private information about a firm's performance to outsiders. According to Miller and Rock (1985), when a company declares dividends, it provides information to its shareholders to forecast the financial position and the earning ability of the company. Jensen and Meckling (1976) developed an agency cost argument which suggests that dividend payouts reduce the cost of funds and increase the cash flows of the firm. After paying cash dividends to stockholders, the firm would have less idle funds in the hands of managers to invest in less or negative NPV projects. Therefore, like signaling theory, agency cost theory support for the argument that dividend payout has strong influence on share price of the firm. The clientele effect shows that the company has different customer groups and these customer groups have different interests, so changes in dividend policy can cause a group of customers to host. Weak dissatisfaction, negatively affecting stock prices (Lewellen et al., 1978). According to the modern portfolio theory (Markowitz, 1952), investors are rational and risk averse -they want to avoid risk unless they are compensated for taking such risk. Investors usually choose less risky investments as they offer more certainty in returns as opposed to investments with higher risk (Kinder, 2002).

\subsection{Literature review}

Studies on the factors affecting stock price movements vary in both the influencing factors and the direction of the factors' influence because the studies are conducted in different countries. Even studies in the same country but at different stages, the results are not similar. An overview of the research on the influence of factors on stock price movements is as follows:

\section{Effects of dividend policy and stock price volatility}

There is a universal relationship of dividend yield and dividend payout ratio with stock price volatility, both developed markets and developing markets.

Firstly, in the context of developed markets like United Stated, United Kingdom, Australia, etc., many researchers have laid the foundations for research on dividend policy and stock price volatility ever since. Black and Scholes (1974) led the research on the relationship between stock price volatility and research dividend policy. In their study, Black and Scholes (1974) created 25 portfolios on the New York Stock Exchange from 1936 to 1966. Using asset capital pricing model to study the relationship 
between policy of dividends and returns that investors receive after adjusting risks and taxes. The variable representing stock price volatility is put into the model by the author in the form of the risk that investors face to obtain the desired profits. The authors concluded that there is no relationship between dividend policy and stock price volatility. Following Black and Scholes (1974), Allen and Rachim (1996) in the context of the Australian stock market. From a sample of 173 companies from 1972 to 1985, they find that share price volatilities of the Australian stock market tend to decrease when dividend payout increases. In addition, their results show that a firm's financial leverage and earnings volatility are positively associated with share price volatilities.

In addition, a study by Baskin (1989) using data from 1967 to 1986 of 2,344 US firms revealed a dominating negative relationship between stock price volatility and dividend yields. The results infer that firms with higher dividend yields were associated with lower risk. The author used regression method to build a model to study the relationship between dividend policy and stock price volatility. The dependent variable was the share price volatility moved along with the independent variables including the group of variables representing dividend policy and the control variables. The variables representing dividend policy were Dividend Payout Ratio and Dividend Yield. Control variables include firm size, asset growth, long-term debt to total assets, and volatility in earnings. He found a negative correlation between dividend rates and dividend payout ratios to stock price volatilities. Control variables such as earning volatility and long-term debt ratios are positively correlated with share price volatilities. In addition, to study the impact of business lines on stock price changes, the author also created 5 dummy variables representing 6 industries that account for a large proportion in the data series. The study concluded that dividend policy had a direct impact on share price volatilities; so, administrators can use this relationship to adjust risk to attract investment. Similar results of Baskin (1989) are noted by Hussainey et al. (2011) in a study of the UK firms from 1998 to 2007, and by Profilet and Bacon (2013) in a study of 599 US-based companies listed on the S\&P 500. Hussainey et al. (2011) investigated the relationship between stock price volatility and two main measurement of dividend policy along with other variables such as size, growth, earnings volatility, and debt based on sample of publicly quoted companies in the UK for 10 years (1998 through 2007). This study found a positive association of dividend yield and a negative association of dividend pay-out ratio with stock price volatility.

Secondly, studies in the context of emerging markets have also been explored. In Pakistan, Nazir et al. (2010) used data of 73 firms listed on the Karachi Stock Exchange (KSE) from 2003 to 2008, and results reveal that dividend yields had a positive relationship share price volatilities, while dividend payout has an opposite negative relationship with the volatility of stock price. Meanwhile, Shah and Noreen (2016) discovered significant negative relationships between the two measures of dividend policy (dividend yields and dividend payout) with share price volatilities. The data employed by Shah and Noreen (2016) differed from that of Nazir et al. (2010), whereby the authors used data of non-financial firms listed on the KSE from year 2005 to 2012. Interestingly, Hamid et al. (2017) revealed a significant positive. However, the varying results may plausibly be due to the sector examined by Hamid et al. (2017), which are financial firms, while Nazir et al. (2010) and Shah and Noreen (2016) studied nonfinancial firms. Hunjra et al. (2014) also attempted to examine the effect of dividend yield, dividend pay-out ratio, earning per share, and return on equity and profit after tax on stock prices with a sample of 63 companies listed at Karachi Stock Exchange for 2006-2011. The results indicated that dividend yield and dividend pay-out ratio had significant impacts on stock price. Dividend yield was negatively related, but the dividend pay-out ratio was positively related with stock price which means that these results were against dividend irrelevance theory. Profit after tax and earnings per share had a significant positive impact on stock price and return on equity which shows positive insignificant impact on stock price. Finally, this study showed new insights for policymakers to improve the performance of Karachi Stock Exchange.

Likewise, in the context of Iran, Lashgari and Ahmadi (2014) attempted to examine the impact of dividend policy on share price volatility in Tehran Stock Exchange. The result indicated that dividend payout ratio had a significantly negative effect, but asset growth rate had a significantly positive effect on stock price volatility. This study also found that variables; namely leverage, earnings volatility and company size on stock price volatility had no significant effect. A number of studies investigating the relationship between dividend policy and share price volatilities have been also conducted in the context of Malaysia. Hashemijoo et al. (2012) used data from 2005 to 2010 to examine the relationship between share price volatilities and dividend policy of 84 consumer products firms listed on Bursa Malaysia. Consistent with past studies, the study revealed that dividend yields and dividend yields were negatively related to share price volatilities. In addition to dividend yields, size of the firm was also strongly related to the share price volatility of Malaysian consumer product companies. However, contradicting results were noted by Zakaria et al. (2012) in a study of 77 construction and material companies listed on Bursa Malaysia from 2005 to 2010. Their results suggest that share price volatilities for construction and material companies were positively related to dividend pay-out. Meanwhile, a study by Sew et al. (2015) employed a large data set of 319 companies from various sectors listed on the Kuala Lumpur Stock Exchange. The study indicated that dividend yield and dividend payout were strongly related to the volatility of stock prices, with a negative sign of relationship. A recent study by Zainudin et al. (2018) analysed the relationship between stock price volatility and dividend policy of industrial products firms listed on Bursa Malaysia. The sample comprised 166 industrial products public-listed firms covering a time span from year 2003 to 2012. Using Baskin's framework, 
firm's stock price volatility was related to dividend pay-out, the empirical results indicate that dividend policy was a strong predictor of stock price volatility of industrial products firms in Malaysia, particularly during the post-crisis period.

In the context of Jordanian industrial firms, Ramadan (2013) examined the impact of dividend policy on share price volatility for 77 Jordanian industrial firms listed at Amman Stock Exchange for 12 years from 2000 to 2011. The results showed a significant negative effect of the dividend policy, dividend yield, and dividend pay-out on the share price volatility. Consistent with past studies, Ramadan (2013) found that increases in dividend yields and dividend payout tend to reduce share price volatility. Al-Shawawreh (2014) conducted a similar study with a sample of 53 companies listed in main market of Bursa Amman in Jordanian Stock Market from 2001 to 2013. The results of this study showed a significant negative relationship of dividend pay-out and a very weak positive relationship of dividend yield with share price volatility. Besides, a significant positive relationship between share price volatility and size is found, and dividend pay-out ratio and stock dividend have the most impact on share price volatility among predictor variables.

In Bangladesh, Haque et al. (2018) investigated the impact of dividend policy on stock price volatility based on 11 years' (from 2004 to 2014) data collected from 35 manufacturing companies listed in Dhaka Stock Exchange (DSE) of Bangladesh. Correlation and multiple regression analysis were used to analyse the association between share price volatility and two main measurement variable of dividend policy (dividend yield and dividend pay-out ratio). Primarily regression model was expanded by adding control variables including size, earning volatility, and debt. The findings of the study suggest that, among predictive variables, dividend yield and size of the firm had major impacts on share price volatility, as the research found the significant inverse relationship of share price volatility with both these variables (dividend yield and size of the firm). In Vietnam, Vietnam's stock market is an emerging market, which began its operation in July 2000. Investors, especially small investors, when joining the market, faced many difficulties when accessing enterprise information in a complete, transparent and proactive manner. The common characteristic of listed enterprises is the high concentrated ownership structure, the state ownership rate accounts for a large proportion. More than $75 \%$ of companies choose to pay cash dividends, the rest is stock dividends or combination of cash and stock dividends. The psychology of Vietnamese shareholders, especially individual investors, is more afraid of risks, and desire to receive dividends at the moment rather than future capital gains (Quyen, 2016). Research by Anh and Nhi (2015) based on data of 165 companies listed on HOSE and Hanoi Stock Exchange (HNX) paying full dividends in 5 years (2009 - 2013), Anh and Nhi (2015) discovered a positive relationship between dividend rates, dividend payout ratios and stock price movements. When the dividend rate in cash or in stock increases, the stock price increases and vice versa. However, the authors found that paying dividends in cash made stock prices more volatile than paying dividends in stocks. Firm size (SIZE) was negatively related to price fluctuations. Large companies usually had less price fluctuations than small businesses. The ratio of long-term debt to total assets (Leverage) was positively related to price volatility. This implies that in the Vietnam stock market, when enterprises increase the level of long-term debt use, the stock price volatility increases, which can be understood because the enterprises that observe most are those that use very little. debt, thus not taking full advantage of financial leverage, when increasing the level of debt use, business value will increase leading to price volatility.

\section{Association between firm size and stock price volatility}

Many empirical researches have documented the effect of firm size on stock volatility. Black (1976 a, b) and Christie (1982) and Cheung and $\mathrm{Ng}$ (1992) argued that smaller firms tend to react more strongly to idiosyncratic shocks and are likely to experience a larger volatility. Sadiq et al. (2013) analysed the stock price volatility by taking non-financial firms listed on Karachi Stock Exchange covering 35 firms from 2001 to 2011. It has identified a positive relationship of price volatility with size and growth in assets of firms. Hashemijoo et al. (2012) investigated the relationship between share price volatility and two main measures of dividend policy and control variables including size, earnings volatility, leverage, debt, and growth. In this study, a significant negative relationship of share price volatility was found with dividend yield, dividend pay-out ratio, and size of the firm. In addition, the results of the study by Al-Shawawreh (2014) conducted with a sample of 53 companies listed in Jordanian Stock Market from 2001 to 2013 showed a significant positive relationship between share price volatility and size. Recently, Haque et al. (2018) suggested that size of the firm have major impact on share price volatility. On the other hand, Lashgari and Ahmadi (2014) indicated that company size on stock price volatility have no significant effect.

\section{Association between earnings volatility and stock price volatility}

Leroy and Porter (1981) and Shiller (1981) report similar findings in their studies-that stock prices were excessively sensitive to the earnings and dividends. Allen and Rachim (1996) found a significant positive correlation among stock price volatility and earning volatility. On the other hand, Sadiq et al. (2013) analyzed the stock price volatility by taking non-financial firms listed on Karachi Stock Exchange covering 35 firms from 2001 to 2011. The study has found that there is no relationship between stock price volatility and earnings volatility of firms in Pakistan. Zainudin et al. (2018) indicated that earning volatility 
significantly explains stock price volatility of industrial product firms during the crisis period.

Relationship between leverage and stock price volatility

Over the years, many researchers have found evidence that higher financial leverage is associated with greater stock market volatility (Black, 1976; Christie, 1982; Schwert, 1989). Allen and Rachim (1996) found a significant positive correlation among stock price volatility and earning volatility and leverage. Nishat and Irfan (2004), on a study on the Karachi Stock Exchange, Pakistan, found that share price volatility is inversely related with both dividend yield and pay-out ratio, while it has got a positive relationship with the size of the firm and leverage. Hussainey et al. (2011) investigated companies in the UK for 10 years (1998 through 2007). Among the control variables in the research model, it was discovered that size and debt had the highest correlation with price volatility. While size had a significant negative relationship with price volatility, suggesting that the larger the firm, the less volatile the stock price is, debt, on the other hand, showed a significant positive relationship with price volatility, suggesting that the more leveraged a firm is, the more volatile the stock price will be. Lashgari and Ahmadi (2014) result indicated that variables leverage, earnings volatility and company size on stock price volatility have no significant effect.

\section{Relationship between firm growth and stock price volatility}

Recently, Sadiq et al. (2013) analysed the stock price volatility by taking non-financial firms listed on Karachi Stock Exchange covering 35 firms from 2001 to 2011. It has identified a positive relationship of price volatility with growth in assets of firms. From the review of literature, it can be seen that the evidence in regard to the effect of dividend policy on share price volatility is inconclusive. After reviewing the studies, the author draws some remarks as follows:

Firstly, the research topic of the influence of factors on stock price volatility has attracted the attention of many scholars around the world but in Vietnam it is still quite modest. Secondly, although many studies have been conducted over the past few decades, the studies have not yet agreed on the effect of dividend policy, volatility of profits, the ratio of long-term debt to total assets, company size, company growth rate to stock price movements. Thirdly, the research data in the studies is general data, not divided by economic groups, so the results are not specific for each type of enterprises. Fourth, most studies have been based on data set for years prior to 2014, so the data are not up to date in recent years.

\section{Hypothesis development}

Dividend policy relates to the management decision on how much of the company's earnings are to be paid out to shareholders as dividends vs retaining for reinvestment in new opportunities. Different researchers have different views about the relationship among dividend policy and stock prices. From an overview of previous studies, this paper has some reviews and hypotheses for the case of listed companies on the Vietnam stock exchange as follows.

First, dividend payments carry information, which is a signal for investors and help investors predicting net income of companies as well as dividend that investors will receive in the future, thus affecting demand for stocks and stock prices in the stock market. Some studies found a positive association of dividend yield and a negative association of dividend pay-out ratio with stock price changes. Besides, several studies indicated that dividend yield and dividend payout are strongly related to the volatility of stock prices, with a negative sign of relationship. In the context of Vietnam market, this paper present hypotheses as follows:

$\mathbf{H}_{1}$ : There is a positive relationship between dividend yield and share price volatility of companies listed on HOSE.

$\mathbf{H}_{2}$ : There is a positive relationship between dividend pay-out ratio and share price volatility of companies listed on HOSE.

Second, the risks of investing in small and medium stocks are relatively large, due to the limited competitiveness of this business group and the level of information transparency is not appreciated. The impact of shocks on prices of small firms is more uncertain and will cause wider price movements and hence larger volatility. In general, small firms are less diversified as compared to larger firms in terms of operations and geographic location. As such, their stock price will tend to experience higher volatility. In the context of Vietnam market, this paper present hypothesis as follows:

H3: There is a positive relationship between firm size and share price volatility of companies listed on HOSE.

Third, dividend is the division of earnings. Companies often divide earnings to shareholders and the rest of earnings for reinvestment. In general, the more stable the earnings of a firm, the more stable its stock price, hence eventually translating into higher dividend payout. In the context of Vietnam market, this paper present hypothesis as follows: 
$\mathbf{H}_{4}$ : There is a positive relationship between earnings volatility of the firm and share price volatility of companies listed on HOSE.

Fourth, companies can raise capital from debt or stock issuance. When borrowing, the company must commit to pay interest to creditor. Therefore, the dividends received by shareholders will be the remaining after paying interest. Therefore, the psychology of shareholders will be affected when companies increased debt ratio because increasing debt will threaten the dividends that shareholders will receive. As a result, debt may affect stock price volatility. When firms issue new debt in a larger proportion to new equity as compared to their prior financial structure, stock volatility increases. In the context of Vietnam market, this paper present hypothesis as follows:

H5: There is a positive relationship between leverage and share price volatility of companies listed on HOSE.

Finally, firms in the growth stage will continue to invest in property, plant and equipment to facilitate the growth required. Firms in this stage are usually retaining more income for new projects, and it is intuitively appealing to think that the earning stream for new projects is more uncertain as compared to existing projects. Therefore, growth is expected to have a direct relationship with share price volatility. The literature suggests that there is an association between growth of assets and share price volatility but there has been no agreement on the direction of growth's impact on volatility of stock prices. In the context of Vietnam market, this paper present hypothesis as follows:

$\mathbf{H}_{6}$ : There is a positive relationship between growth and share price volatility of companies listed on HOSE

\section{Research Methodology}

\subsection{Data Collection}

Currently, there are 371 companies trading on HOSE. From these 371 companies, the authors selected non-financial companies with the same accounting year-ending on December 31 each year and have sufficient data for 7 variables in the model for 10 years. We excluded financial companies from our sample because financial firms have a different accounting system than the other firms. Therefore, the research sample in this study collected from 260 non-financial companies listed on HOSE over a tenyear period from 2009 to 2018 provided by FiinGroup JSC. Research data is extracted from the audited financial statements of these companies.

\subsection{Research Model}

PVol $_{\mathrm{i}}=\alpha_{0}+\alpha_{1}$ DYield $_{\mathrm{i}}+\alpha_{2}$ DPayout $_{\mathrm{i}}+\alpha_{3}$ Earning ol $_{\mathrm{i}}+\alpha_{4} \mathrm{SIZE}_{\mathrm{i}}+\alpha_{5} \mathrm{GROWTH}_{\mathrm{i}}+\alpha_{6} \mathrm{LEV}_{\mathrm{i}}+€$

where:

Pvol: Share price volatility. This is the dependent variable.

DYield: Dividend yield. This is expressed as the dividend per share as a percentage of the share price.

Dpayout: Payout ratio. This is the ratio of dividends per share to earnings per share.

SIZE: Firm size

EarningVol: Earning Volatility

LEV: Leverage

GROWTH: Growth of firm assets

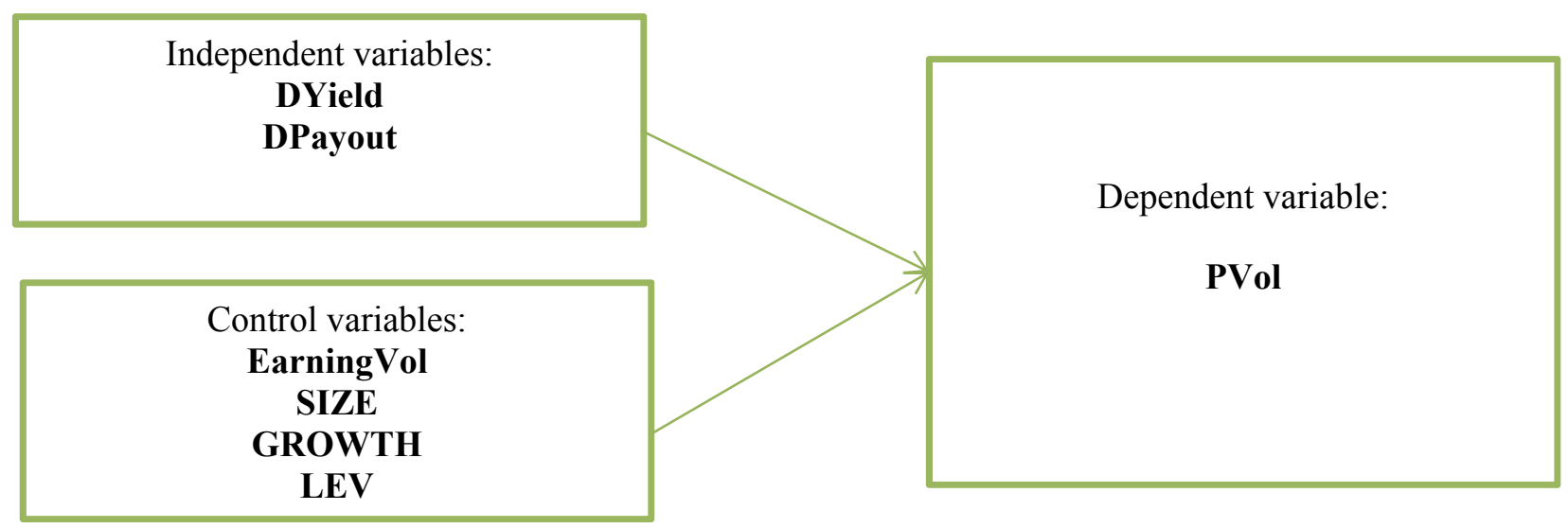

Fig. 1. Research Model (Source: Compiled by the authors) 
Variable names and measurements in the model are explained in Table 1 as follows,

Table 1

Measurement of variables used in research model

\begin{tabular}{|c|c|c|c|}
\hline Variables & Variable Name & Measurement & Previous studies \\
\hline PVol & $\begin{array}{l}\text { Share Price } \\
\text { volatility }\end{array}$ & $\begin{array}{l}\text { Firstly, the annual range of stock price for all available years was collected to find the } \\
\text { highest price and lowest price of the year. Secondly, for each year, the range is divided } \\
\text { by the average of the high and the low, and then raised to the second power. Finally, } \\
\text { the average measures of variances for all available years are then transformed into } \\
\text { standard deviations by using a square root transformation. }\end{array}$ & $\begin{array}{l}\text { Baskin(1989), Hashemijoo et } \\
\text { al. (2012); Sew et al. (2015); } \\
\text { Shah and Noreen (2016); } \\
\text { Zainudin et al. (2018) }\end{array}$ \\
\hline DYield & Dividend yield & $\begin{array}{l}\text { Dividend yield is determined from total dividends per share declared during the fiscal } \\
\text { year divided by the market price of the company's }\end{array}$ & $\begin{array}{l}\text { (Hussaineyetal., } 2011 ; \\
\text { Hashemijooetal., 2012; } \\
\text { Sewetal., 2015; Shah and } \\
\text { Noreen, 2016; Zainudin et al. } \\
\text { (2018) }\end{array}$ \\
\hline DPayout & $\begin{array}{l}\text { Dividend Pay- } \\
\text { out ratio }\end{array}$ & Dividend Pay-out ratio based on the ratio of dividends per share to earnings per share & $\begin{array}{l}\text { Wild et al., 2007; Marshall et } \\
\text { al., 2011; Sew et al., 2015; Shah } \\
\text { and Noreen, 2016; Zainudin et } \\
\text { al. (2018) }\end{array}$ \\
\hline EarningVol & $\begin{array}{l}\text { Earning } \\
\text { Volatility }\end{array}$ & $\begin{array}{l}\text { First, the ratio of earnings before interest and tax (EBIT) for each year is calculated. } \\
\text { The average over ten years is then computed, then raised to second power. The standard } \\
\text { deviation is obtained by using a square root transformation on the average amount. }\end{array}$ & $\begin{array}{l}\text { Allen and Rachim (1996); } \\
\text { Zakaria et al. (2012); Zainudin } \\
\text { et al. (2018) }\end{array}$ \\
\hline LEV & $\begin{array}{l}\text { Long-term debt } \\
\text { to total assets. }\end{array}$ & $\begin{array}{l}\text { The ratio of long-term debt to total assets was calculated and the average over all } \\
\text { available years was utilized. }\end{array}$ & Haque et al. (2018) \\
\hline GROWTH & Growth in assets & $\begin{array}{l}\text { These figures were obtained by taking the ratio of the change in total assets at the end } \\
\text { of the year to the level of total assets at the beginning of the year. These figures were } \\
\text { averaged over all available years. Then, the average of the ratio over the ten-year period } \\
\text { is computed }\end{array}$ & $\begin{array}{l}\text { Baskin (1989); Allen \& Rachim } \\
\text { (1996), Hashemijoo et al. } \\
\text { (2012); Sew et al. (2015); } \\
\text { Zainudin et al. (2018) }\end{array}$ \\
\hline
\end{tabular}

(Source: Compiled by the authors)

\subsection{Research Design}

The relationship between ordinary stock price volatility and dividend policy has been analyzed by utilizing regressions. The regression model developed basically relates price volatility with the two main measures of dividend policy - dividend yield and dividend payout ratio. In line with the recommendations by Baskin (1989), number of control variables were included to account for certain factors that affect both dividend policy and stock price volatility like asset growth, earnings volatility, leverage and firm size. Following the regression of FEM and REM, the authors checked the model validity and verify the compliance with important assumptions such as no autocorrelation, constant variance or multicollinearity. The model validity is tested by examining the F-statistic value from regressions (i.e., Prob (F-statistic) $<0.1$ means a valid model). The constant variance is checked by Breusch-Pagan-Godfrey test, which tests the null hypothesis that all error variances are equal versus the alternative that the error variances are a multiplicative function of one or more variables. If the Prob (F-statistic) value obtained after this test is less than 0.1 , the paper concludes that the error variances are not equal (constant variance). In this research, testing results revealed that REM and FEM models invalid from the regressions, so that the Generalized Method of Moments (GMM) is employed as suggested by Hansen (1982) to provide more accurate and reliable results. According to Driffill et al. (1998), the GMM regression method is better than the usual regression method on panel data in checking the movement of financial variables. This paper uses Hansen (1982) test to determine the suitability of the tool variables in GMM estimation and Arellano - Bond test proposed by Arellano - Bond (1991) to check the autocorrelation.

Hansen test is as follows:

Ho: instrumental variables are exogenous, which means they are not correlated with the model errors.

If the p-value obtained by Hansen test is as large as possible, it means that the GMM model is suitable. This paper uses p-value 
greater than 0.05 to conclude the GMM model is suitable.

The second-order correlation test of Arellano - Bond (1991) is as follows:

Ho: no second-order correlation.

If the p-value obtained by Hansen test is greater than 0.05 , it means that the model does not exist second-order correlation

According to Trong and Ngoc (2013), multicollinearity is the phenomenon of independent variables very strongly related to each other. The model with multi-collinear phenomenon happening will make the regression coefficients obtained unreliable. In this paper, to test multicollinearity, this paper is based on the value of the VIF coefficient. Trong and Ngoc (2013) stated that if VIF value is less than 10, the model has no multicollinearity whereas VIF is greater than 10, there must be multicollinearity.

\section{Results and Discussion}

\subsection{Descriptive Statistic}

\section{Table 2}

Descriptive Statistics

\begin{tabular}{|c|c|c|c|c|c|}
\hline Variable & Obs & Mean & SD & Min & Max \\
\hline PVol & 2,442 & 0.451471 & 0.45404 & 0 & 4 \\
\hline DYield & 1,798 & 0.080078 & 0.054522 & 0.005025 & 0.880658 \\
\hline Dpayout & 1,802 & 0.855049 & 5.557838 & -9.95136 & 206.2727 \\
\hline GROWTH & 2,435 & 0.157227 & 0.365599 & -0.59461 & 6.507917 \\
\hline SIZE & 2,436 & $3.58 \mathrm{E}+12$ & $1.75 \mathrm{E}+13$ & 0 & $3.04 \mathrm{E}+14$ \\
\hline EarningVol & 2,330 & 48.35512 & 3.392571 & 27.99516 & 59.1001 \\
\hline LEV & 2,442 & 0.1174 & 0.14755 & 0 & 0.718176 \\
\hline
\end{tabular}

(Source: Results of data processing of the authors)

The statistics (Table 2) show that: companies listed on the Ho Chi Minh Stock Exchange have an average of $45 \%$ of the stock price changes (Mean of PVol $=0.451471)$, with an dividend pay-out ratio of $8 \%$ (Mean of DYield $=0.08)$, dividend pay-out ratio is $85 \%$ (Mean of Dpayout $=0.85$ ), average annual asset growth is $15 \%$ (Mean of GROWTH $=0.157227$ ), capital size on the market about VND 358 billion and debt to total assets ratio is $11.74 \%$ (Mean of LEV $=0.1174$ ).

\subsection{Correlation analysis}

Table 3

Correlation coefficient

\begin{tabular}{|c|c|c|c|c|c|c|c|}
\hline Variables & PVol & DYield & DPayout & GROWTH & SIZE & EarningVol & LEV \\
\hline PVol & 1 & & & & & & \\
\hline DYield & 0.0218 & 1 & & & & & \\
\hline Dpayout & -0.0126 & 0.0461 & 1 & & & & \\
\hline GROWTH & 0.1673 & -0.1042 & 0.0849 & 1 & & & \\
\hline SIZE & -0.0418 & -0.1172 & -0.005 & 0.0307 & 1 & & \\
\hline EarningVol & 0.0621 & -0.1412 & -0.0078 & 0.1331 & 0.3394 & 1 & \\
\hline LEV & 0.01 & -0.0157 & -0.006 & 0.0473 & -0.0121 & 0.0685 & 1 \\
\hline
\end{tabular}

(Source: Results of data processing)

According to the statistics obtained from the regression analysis as shown in Table 3, PVol has a positive relationship with DYield, GROWTH, EarningVol and LEV and the opposite relationship with Dpayout, SIZE.

\subsection{Empirical results}

As the results of regression analysis by GMM method show that the value of VIF coefficient is less than 10 , there is no multicollinear phenomenon; p-value of AR (2) and Hansen test are more than 0.05 so the GMM model used in this research is reliable.

\section{Table 4}

Test results

\begin{tabular}{lc}
\hline Test & Value \\
\hline AR(2) & 0.202 \\
Hansen test & 0.094 \\
VIF & $<10$ \\
\hline
\end{tabular}

(Source: Results of data processing of the authors) 
Table 5

Regression results

\begin{tabular}{|c|c|c|c|}
\hline Variables & FEM & REM & GMM \\
\hline PVol & & & $0.157 * * *$ \\
\hline DYield & $0.920 * * *$ & $0.824 * * *$ & $0.571 * * *$ \\
\hline Dpayout & $-0.00417 * *$ & -0.00194 & $-0.0307 * * *$ \\
\hline GROWTH & $0.149 * * *$ & $0.177 * * *$ & $0.162 * * *$ \\
\hline SIZE & $-0.0620 * * *$ & $-0.0355 * * *$ & $-0.0453 * * *$ \\
\hline EarningVol & -0.000891 & $0.0108 * * *$ & $0.00907 * * *$ \\
\hline LEV & -0.204 & -0.0435 & $0.782 * * *$ \\
\hline Constant & $2.017 * * *$ & $0.727 * * *$ & $0.943 * * *$ \\
\hline Observations & 1,597 & 1,597 & 1,492 \\
\hline Number of i & 260 & 260 & 253 \\
\hline
\end{tabular}

Standard errors in parentheses

$* * * \mathrm{p}<0.01, * * \mathrm{p}<0.05, * \mathrm{p}<0.1$

(Source: Results of data processing of the authors)

In this research, because REM and FEM models are found invalid from the regressions, the Generalized Method of Moments (GMM) is employed as suggested by Hansen (1982) to provide more accurate and reliable results. According to GMM regression results, the independent variables in the research model (DYield, DPayout, GROWTH, SIZE, EarningVol, LEV) are all closely related and statistically significant with dependent variable in the model (PVol) (p-value obtained from estimated model less than 0.01). Specifically, the relationship between PVol and DYield, GROWTH, EarningVol, LEV is the same direction (shown in the regression coefficient's values of $0.571 ; 0.162,0.00907 ; 0.7822$, respectively) and the relationship between PVol and DPayout, SIZE is opposite (shown in negative regression coefficients' values of -0.0307 and -0.0453 , respectively).
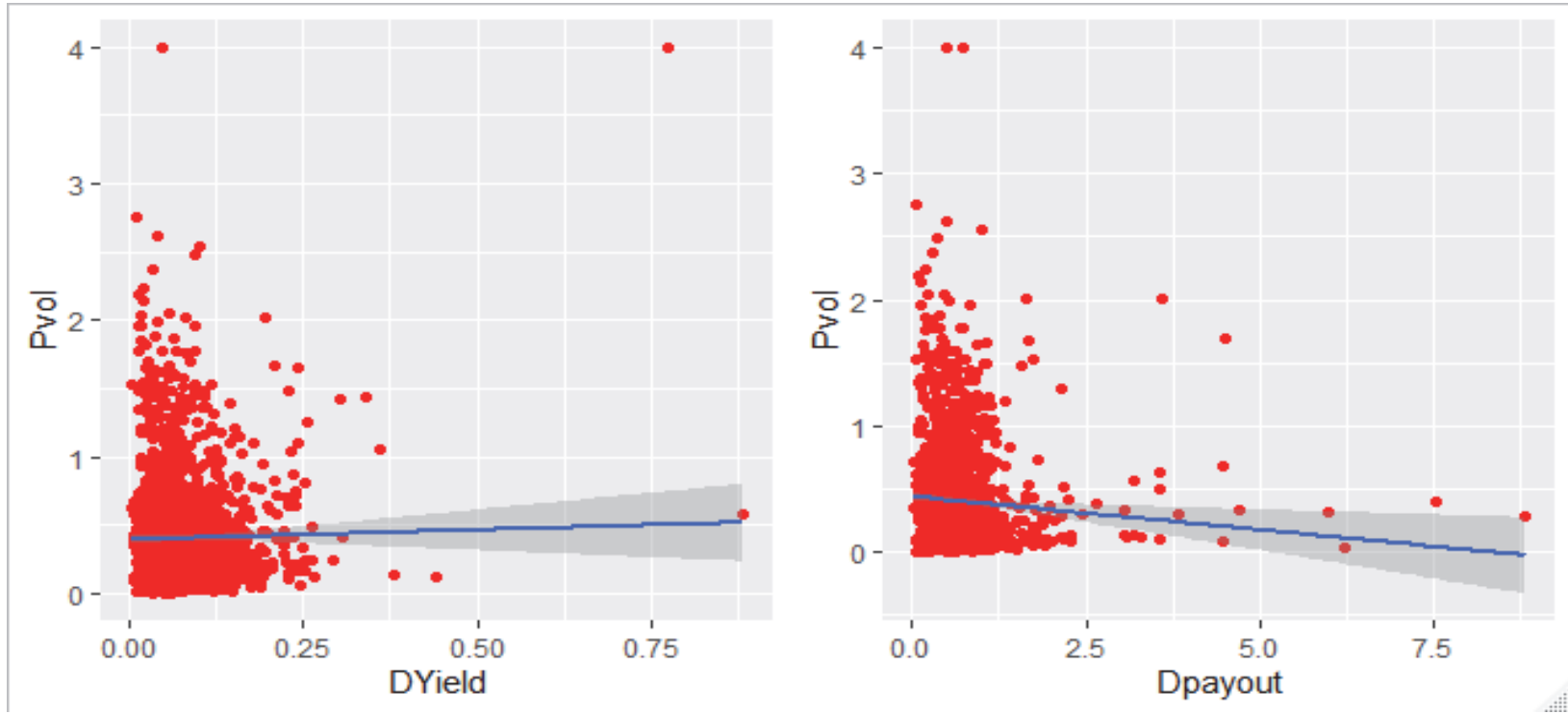

Fig. 2. The relationship DYield, DPayout and PVol

\section{Discussion and recommendations}

\subsection{Discussion}

Firstly, the regression results show that the dividend payment ratio is positively related to the share price volatility (regression coefficient $=0.571$ and statistically significant). This means that for companies listed on the HOSE, the more the company pays dividends, the more volatile its share price is. Thus, hypothesis H1 is accepted. The results of this study are consistent with the findings of the authors Baskin (1989), Hussainey et al. (2011); Nazir et al. (2010); Anh and Nhi (2015) but not in the same opinion as Hussainey et al. (2011); Hashemijoo et al. (2012).

Secondly, the dividend payment ratio is negatively related to the share price volatility (regression coefficient $=-0.0307$ and statistically significant). This shows that, for companies listed on the HOSE, when the company raises the interest payment ratio for its shareholders, the stock price movement will decrease, the stock price will be more stable. 
Thus, the hypothesis $\mathrm{H} 2$ is not accepted. The results of this study are consistent with the results of the authors such as Allen and Rachim (1996); Hussainey et al. (2011); Hashemijoo et al. (2012) Lashgari and Ahmadi (2014); Noreen (2016) but does not agree with Baskin (1989).

Thirdly, the size of the firm, or the capitalization of the firm found in this study, is negatively related to share price volatility. Thus, the research hypothesis H3 is accepted. The results of this study are in agreement with the results of many studies conducted such as those of Hashemijoo et al. (2012), Anh and Nhi (2015) but not in agreement with the studies of Al-Shawawreh (2014) and Lashgari and Ahmadi (2014).

Fourth, profit volatility is also positively related to stock price movements. This means that for companies listed on the HOSE, when volatile profits will affect demand for shares in the market and make stock prices fluctuate accordingly. Thus, research hypothesis H4 is accepted. This research is consistent with the results of Leroy and Porter (1981); Shiller (1981); Allen and Rachim (1996) and Zainudin et al. (2018)

Fifth, the debt ratio has a positive effect with stock price movements. The more companies borrowed, the more the share price fluctuated. Thus, research hypothesis H5 is accepted. This research result is consistent with the research results of the authors Black (1976); Christie (1982); Schwert (1989); Allen and Rachim (1996); Hussainey et al. (2011)

Finally, the research results show that the growth rate of assets is positively related to stock price fluctuations. As the company's total assets increase, so does the volatility of the stock. Thus, the research hypothesis H6 is accepted. The results of this study are consistent with the findings of the authors like Zainudin et al. (2018) and Sadiq et al. (2013)

\subsection{Recommendations}

In recent years, income from dividends has begun to be interested by investors in Vietnam's stock market; However, most companies do not realize the importance of dividend policy and do not have clear and long-term orientations for profit distribution policy. The late payment of dividends, dividend debt takes place in many companies. Investors, especially individual investors, are always passive before stock price movements, making it difficult to set up investment plans to achieve the set goals. This article hopes to provide more useful information to help investors and businesses make appropriate decisions in their own conditions. Dividend policy affects changes in stock prices, thereby affecting the value of the business. The decision on dividend policy is a very important decision for businesses, even though the stock market is not as developed as in Vietnam. Obviously, it is difficult to provide a dividend policy that is considered a model for all businesses, because dividend policy is in a harmonious relationship between investment policy and sponsorship policy. However, each business depends on its business characteristics and current market conditions to have different investment and development policies. Therefore, the policy recommendations are made based on the research results of the model combined with the current status of dividend payment of businesses listed on the Vietnamese stock market. On the investor side, in order to achieve its investment goals, it is also advisable to take advantage of information about dividends of the enterprise used to analyse the company, choose to invest in enterprises with consistent, clear and stable dividend policy while choosing priority investment in businesses with high growth potential but low stock market prices. For the company managers: companies should try to maintain a safe dividend rate, small quarterly dividend policy combined with year-end dividend bonus should be considered and used for businesses listed on the stock market. From the research results show that, the more the company increases debt, the price fluctuation will increase. Therefore, the company needs to be cautious in deciding to raise capital by using debt instruments because it affects stock prices and thus affects equity and thus the capital raising goal may not be achieved.

\section{Conclusion}

This article has studied the factors affecting the stock price fluctuations of non-financial companies listed on HOSE. Empirical evidence has shown that DYield had a negative relationship with PVol but Dividend Pay-out ratio had the same effect with PVol. In addition, asset fluctuations, profit fluctuations, and the ratio of debt to total assets are positively related to stock price movements. However, firm size was inversely related to stock price movements. The relationship between dividend policy and share price volatility was quite significant to investors, policy makers, portfolio managers and researchers who were interested in capital market on decision making activities with the perspective of investment risk. Therefore, the managers should be knowledgeable enough to make decisions on valuation of shares, investment and dividend decisions in wide manner. To expand future studies, it should be focused on expanding the sample size by focusing on different sectors in HOSE to find out the different aspects of share price volatilities on various dividend policies. Furthermore, this research area can be integrated with emerging markets more over than Vietnam to identifying or establishing relationship between share price volatility and dividend policy in global perspective. 
Allen, D.E., \& Rachim, V.S. (1996). Dividend policy and stock price volatility: Australian evidence. Applied Financial Economics, 6(2), 175-188. DOI: 10.1080/096031096334402

Anh, Đ.T.Q., \& Nhi, P.T.Y. (2016). The factors affect to the dividend policy of joint - stock companies listed on the Vietnam's Stock Market. In Vietnamese: Impact of dividend policy on stock price movements of companies listed on Vietnam's stock market. Journal of Development and Integration, 26(36).

Al-Shawawreh, F. K. (2014). The impact of dividend policy on share price volatility: Empirical evidence from Jordanian stock market. European Journal of Business and Management, 6(38), 133-143.

Arellano, M., \& Bond, S. (1991). Some tests of specification for panel data: Monte Carlo evidence and an application to employment equations. The Review of Economic Studies, 58, 277-297

Black, F. (1976a). Studies of stock price volatility changes. Proceedings of the 1976 Meetings of the American Statistical Association, Business and Economics Section, 3(1-2), 177-181.

Black, F. (1976b). The dividend puzzle. The Journal of Portfolio Management, 2(2), 5-8.

Baskin, J. (1989). Dividend policy and the volatility of common stocks. The Journal of Portfolio Management, 15, 19-25.

Ball, R., Brown, P., Finn, F.J., \& Officer, R.R. (1979). Dividends and the value of the firm: evidence from the Australian equity market. Australian Journal of Management, 4(1), 13-26.

Bhattacharya, S. (1979). Imperfect information, dividend policy, and "The Bird in The Hand" fallacy. Bell Journal of Economics, 10, 259-270.

Black, F., \& Scholes, M. (1974). The effects of dividend yield and dividend policy on common stock prices and returns. Journal of Financial Economics, 1, 1-22.

Brennan, M. (1971). A note on dividend irrelevance and the Gordon valuation model. The Journal of Finance, 26, 1115-1121.

Christie, A.A. (1982). The stochastic behaviour of common stock variances: value, leverage and interest rate effects. Journal of Financial Economics, 10(4), 407-432.

Cheung, Y.W. and Ng, L.K. (1992). Stock price dynamics and firm size: an empirical investigation. The Journal of Finance, 47(5), 1985-1997.

Driffill, J., Psaradakis, Z., \& Sola, M. (1998). Testing the expectations hypothesis of the term structure using instrumental variables. International Journal of Finance and Economics, 3(4), 321-325.

Gordon, M. J. (1959). Dividends, earnings \& stock prices. Review of Economics and Statistics, 41(May), 99-105.

Gordon, M.J. (1963). Optimal investment and financing policy. The Journal of Finance, 18(2), 264-272.

Hansen, L.P. (1982). Large sample properties of generalized methods of moments estimators. Econometrica, 50, 1029-1054.

Harkavy, O. (1953). The relation between retained earnings and common stock prices for large listed corporations. Journal of Finance, 8(3), 283-297.

Trong, H., \& Ngoc, C.N.M. (2013). Statistics applied in socio-economic research. Statistical Publishing House, Hanoi

Hashemijoo, M., Ardekani, A. M., \& Younesi, N. (2012). The impact of dividend policy on share price volatility in the Malaysian Stock Market. Journal of Business Studies Quarterly, 4(1), 111- 129.

Hamid, K., Khurram, M.U., \& Ghaffar, W. (2017), Juxtaposition of micro and macro dynamics of dividend policy on stock price volatility in financial sector of Pakistan: (comparative analysis through common, fixed, random and GMM effect. Journal of Accounting, Finance and Auditing Studies, 3(1), 64-79.

Hunjra, A., Shahzad, M., Chani, M. I., Hassan, S., \& Mustafa, U. (2014). Impact of dividend policy, earning per share, return on equity, profit after tax on stock prices. International Journal of Economics and Empirical Research, 2(3), 109-115.

Haque, R., Jahiruddin, A. T. M., \& Mishu, F. (2019). Dividend policy and share price volatility: A study on Dhaka Stock Exchange. Australian Academy of Accounting and Finance Review, 4(3), 89-99.

Hussainey, K., Mgbame, C.O, \& Chijoke Mgbame, A.M. (2011). Dividend policy and share price volatility: UK evidence. The Journal of Risk Finance, 12(1), 57-68, https:// doi.org/10.1108/15265941111100076

Jensen, M.C., \& Meckling, W.H. 2016). Theory of firm: Managerial behaviour, agency costs and ownership Structure. Journal of Financial Economics, 3, 305-350.

Kinder, C. (2002). Estimating stock volatility. Available at: www.bryongaskin.net (accessed 2 December 2014).

Lewellen, W. G., Stanley, K. L., Lease, R. C., \& Schlarbaum, G. G. (1978). Some direct evidence on the dividend clientele phenomenon. The Journal of Finance, 33(5), 1385-1399.

Lashgari, D., \& Ahmadi, M. (2014). The impact of dividend policy on stock price volatility in the Tehran Stock Exchange. Kuwait Chapter of Arabian Journal of Business and Management Review, 3(10), 273-283.

LeRoy, S.F., \& Porter, R.D. (1981). The present-value relation: tests based on implied variance bounds. Econometrica: Journal of the Econometric Society, 49(3), 555-574.

Lintner, J. (1956). Distribution of incomes of corporations among dividends, retained earnings, and taxes. The American Economic Review, 46, 97-113.

Markowitz, H. (1952). Portfolio Selection. The Journal of Finance 7(1), 77-91.

Miller, M.H., \& Rock, K. (1985). Dividend policy under asymmetric information. The Journal of Finance, 40(4), 1031-1051. 
Miller, M.H., Modigliani, F. (1961). Dividend policy, growth, and the valuation of shares. The Journal of Business, 34, 411433.

Nazir, M.S., Nawaz, M.M., Anwar, W., \& Ahmed, F. (2010). Determinants of stock price volatility in Karachi stock exchange: the mediating role of corporate dividend policy. International Research Journal of Finance and Economics, 55, 100-107.

Nishat, M., \& Irfan, C. M. (2004). Dividend policy and stock price volatility in Pakistan. Paper presented at the PIDE-19th Annual General Meeting and Conference, Islamabad.

Pettit, R.R. (1972). Dividend announcements, security performance, and capital market efficiency. The Journal of Finance, 27(5), 993-1007.

Quyen, N.T (2016). The factors affect to the dividend policy of joint - stock companies listed on the Vietnam's Stock Market. The factors affect to the dividend policy of joint - stock companies listed on the Vietnam's Stock Market. PhD thesis, National Economics University.

Ramadan, I.Z. (2013). Dividend policy and price volatility: empirical evidence from Jordan. International Journal of Academic Research in Accounting, Finance and Management Sciences, 3(2), 15-22.

Sadiq, M., Ahmad, S., Anjum, M.J., Suliman, M., Abrar, S.U. \& Khan, S.U.R. (2013). Stock price volatility in relation to dividend policy; A case study of Karachi Stock Market. Middle-East Journal of Scientific Research, 13(3), 426-431.

Shah, S.A., \& Noreen, U. (2016). Stock price volatility and role of dividend policy: empirical evidence from Pakistan. International Journal of Economics and Financial Issues, 6(2), 461-472.

Shiller, R.J. (1981). Do stock prices move too much to be justified by subsequent changes in dividends? The American Economic Review, 71(3), 421-436.

Schwert, G.W. (1989). Why does stock market volatility change over time? The Journal of Finance, 44(5), 1115-1153.

Sew, E.H., Albaity, M., \& Ibrahimy, A.I. (2015). Dividend policy and share price volatility. Investment Management and Financial Innovations, 12(1), 226-234.

Walter, J.E. (1963). Dividend policy: Its influence on the value of the enterprise. The Journal of Finance, 18, 280-291.

Woolridge, J.R. (1983). Dividend changes and security prices. The Journal of Finance, 38(5), 1607-1615.

Zakaria, Z., \& Shamsuddin, S. (2012). Empirical evidence on the relationship between Stock Market Volatility and macroeconomics volatility in Malaysia. Journal of Business Studies Quarterly, 4(2), 61-71.

Zainudin, R., Mahdzan, N., \& Yet, C. (2018). Dividend policy and stock price volatility of industrial products firms in Malaysia. International Journal of Emerging Markets, 13(1), 203-217.

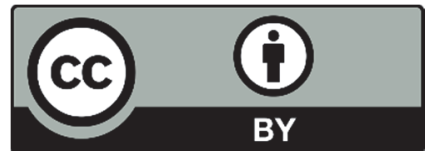

(C) 2020 by the authors; licensee Growing Science, Canada. This is an open access article distributed under the terms and conditions of the Creative Commons Attribution (CC-BY) license (http://creativecommons.org/licenses/by/4.0/). 